Vol. 2 No. 2 Juli 2019

ISSN 2614-2775

e-ISSN 2621-8143
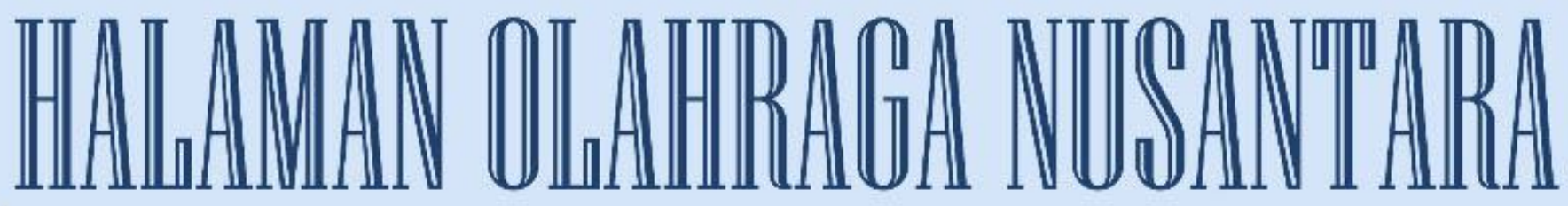

Surnal @lmu Xeolahragaan

Diterbitkan Oleh:

Program Studi Pendidikan Olahraga

Fakultas Keguruan dan Ilmu Pendidikan

Universitas PGRI Palembang

\begin{tabular}{|c|c|c|c|c|c|}
\hline Jurnal & Volume & Nomor & Halaman & Palembang & ISSN/e-ISSN \\
\hline IIalaman Oahrayg Ninsantarata & 2 & 2 & $97-197$ & 2019 & $\begin{array}{c}2614-2775 / \\
2621-8143\end{array}$ \\
\hline
\end{tabular}


Halaman Olahraga Nusantara (Jurnal Ilmu Keolahragaan)

P-ISSN 2614-2775

Volume 2, No. 2, Januari 2019

E-ISSN 2621-8143

\section{DAFTAR ISI}

Hasil Penelitian

Halaman

Penerapan Model Permainan Rounders Yang Dimodifikasi Terhadap Kemampuan Gerak Dasar Murid Sd Negeri Paccinongan Kabupaten Gowa

- Benny B, M.Rachmat Kasmad

Pelaksanaan Kegiatan Belajar Mengajar Pendidikan Jasmani di Sekolah Dasar Inklusi

- Bambang Gatot Sugiarto

Pengaruh Metode Latihan Terhadap Daya Tahan Fisik Siswa Ekstrakurikuler Sepak Bola Sma N 2 Tanjung Raja

- Mutiara Fajar.

Survei Minat Member Yang Mengikuti Fitness Pada Pusat Kebugaran Kota Palembang

- Hengki Kumbara.

Peningkatan Pengaruh Latihan Kelincahan Terhadap Kemampuan Menggiring Bola Pada Siswa Sma Negeri 3 Samarinda

- Ruslan, Nurjamal

Penerapan Permainan Dengnan Media Swiss Ball Untuk Meningkatkan Kelentukan Lower Back (Pada Mahasiswa Kop Aerobic Gymnastics Universitas Negeri Jakarta)

- M Dian Susanto, Sri Nuraini $141-153$

Patrol Multiguna Sebagai Alternatif Media Pembelajaran Tolak Peluru Di Smp Negeri 1 Sei Balai Kabupaten Batu Bara Tahun Ajaran 2017/2018

- Joko Priono $154-166$ 
Kecerdasan Gerak Dalam Pendidikan Jasmani

- Hilda Oktriyeni....................................................................... 167-176

Analisis Kesalahan Tendangan Atlet Pencak Silat Universitas PGRI Palembang

- Bayu Iswana............................................................................ 177-185

Pengaruh Metode Pembelajaran Dan Kriteria Layanan Bantuan:

Meningkatkan Gerak Dasar Lompat Jauh Gaya Jongkok Siswa Tunagrahita Ringan Pada Pembelajaran Penjasorkes SLB PKK Bandar Lampung

- Rachmi Marsheilla Aguss.............................................................. 186-197 


\title{
PENINGKATAN PENGARUH LATIHAN KELINCAHAN TERHADAP KEMAMPUAN MENGGIRING BOLA PADA SISWA SMA NEGERI 3 SAMARINDA
}

\author{
Oleh: Ruslan, Nurjamal \\ ( Dosen Universitas Mulawarman)
}

\begin{abstract}
Abstrak
Penelitian ini bertujuan untuk mengetahui pengaruh latihan Pengaruh Latihan Kelincahan Terhadap Kemampuan Menggiring Bola Pada Siswa SMA Negeri 3 samarinda. Jenis penelitian ini adalah penelitian eksperimen. Populasi dalam penelitian ini adalah keseluruhan siswa SMA Negeri 3 samarinda yang berjenis kelamin laki-laki. Pengambilan sampel menggunakan sistem random sampling, terbagi ke dalam 2 kelompok yaitu kelompok A dengan latihan Latihan Lari Zig-Zag dan kelompok B dengan Latihan Jongging Run. Setiap kelompok terdiri dari 15 orang sampel. Jadi jumlah keseluruhan sampel sebanyak 30 orang. Teknik analisis data yang digunakan adalah statistik deskriptif dan statistik inferensial dengan menggunakan teknik uji t-test. Hasil penelitian menunjukkan bahwa: 1). Ada pengaruh antara latihan Lari Zig-Zag Terhadap Kemampuan Menggiring Bola Pada Siswa SMA Negeri 3 samarinda, diperoleh nilai $t_{o}=8.174$ $\geq t_{0,05}=2,145$ dengan nilai probabilitas signifikansi yang diperoleh 0,000 $<\alpha$ 0,05; 2). Ada pengaruh antara latihan Jongging Run Terhadap Kemampuan Menggiring Bola Pada Siswa SMA Negeri 3 samarinda, diperoleh nilai $t_{o}=7.645$ $\geq t_{0,05}=2,145$, dengan nilai probabilitas signifikansi yang diperoleh $0,000<\alpha$ 0,05; 3). Ada perbedaan pengaruh latihan Pengaruh Latihan lari Zig-Zag Dan Latihan Jongging Run Terhadap Kemampuan Menggiring Bola Pada SMA Negeri 3 samarinda yang diperoleh $0,000<\alpha 0,05=0.281$
\end{abstract}

Kata Kunci : Kelincahan, lari zig-zag, Jongging Run, Menggiring Bola

\section{IMPROVING THE INFLUENCE OF FAMILY EXERCISE ON ABILITY TO FLASH THE BALL SAMARINDA 3 STATE HIGH SCHOOL STUDENTS}

\begin{abstract}
This study aims to determine the effect of the exercise of the Effect of Agility Exercises on the Ability of Herding Ball in Students of SMA Negeri 3 samarinda. This type of research is experimental research. The population in this study were all SMA Negeri 3 students who were male. Sampling using a random sampling system, divided into 2 groups, namely group A with Zig-Zag Running Training exercises and group B with Jongging Run Exercises. Each group consisted of 15 samples. So the total number of samples is 30 people. The data analysis technique used is descriptive statistics and inferential statistics using the t-test test technique. The results of the study show that: 1). There is an influence between Running Zig-Zag Exercises Against the Ability of Dribbling Ball in Students of SMA Negeri 3 Samarinda, obtained a value of $=8.17474$ t0.05 =
\end{abstract}


2.145 with a probability value of significance obtained $0,000<\alpha 0.05 ; 2)$. There is an influence between Jongging Run exercises on the ability to herd the ball in students of SMA Negeri 3 Samarinda, the value to $=7.645 \geq t 0.05=2.145$, with the probability value obtained $0,000<\alpha 0,05 ; 3)$. There is a difference in the effect of training on the Effect of Zig-Zag Running Exercises and Jongging Run Exercises on the Ability of Ball Dribbling in the District 3 of SMA Negeri 0.000 $<\alpha 0.05=0.281$

Keywords: Agility, zigzag running, Jongging Run, Ball dribbling

\section{A. PENDAHULUAN}

Sepak bola merupakan salah satu permainan yang paling banyak digemari banyak orang, baik dari kalangan bawah menengah maupun kalangan atas. Di Indonesia sepak bola sudah merupakan permainan rakyat, hal ini dapat kita lihat bahwa diseluru pelosok tanah air ada lapangan sepak bola dan banyak orang yang memainkannya, baik mulai klub sepak bola maupun yang hanya sekedar hobi. Namun demikian perkembangan sepak bola Indonesia di lingkup Asia maupun Internasional belum seperti yang di harapkan.Permainan sepak bola merupakan salah satu cabang olahraga beregu yang populer dewasa ini di seluruh dunia terutama dikawasan, Eropa, Amerika dan Asia. Di tanah air kita pun permainan sepak bola sudah dikenal cukup lama, dan merupakan salah satu permainan rakyat yang sangat digemari dan sudah memasyarakat, baik masyarakat perkotaan maupun masyarakat perdesaan, mulai dari anak-anak kecil, remaja, sampai orang tua sangat menggemarinya. Hal ini disebabkan oleh sifat permainannya itu sendiri yang mempunyai ciri khas yaitu mudah dilakukan, menyenangkan dan tidak memerlukan biaya yang mahal, serta permainan sepak bola ini dapat pula menjadi suatu alat pemersatu dalam menjalin persaudaraan, kerjasama antar bangsa. Dalam menggiring bola seorang pemain harus dapat merubah arah dan melewati lawan dengan cepat serta harus dapat menggunakan seluruh bagian kakinya sesuai dengan yang ingin dicapai. Untuk dapat melakukan semua itu sangat dibutuhkan unsur fisik karena dukungan fisik yang baik diharapkan seorang pemain atau atlet akan dapat bermain dengan baik pula.Dari berbagai teknik dasar yang disebut di atas, maka yang akan di bahas secara mendalam adalah pengaruh dari bentukbentuk latihan penunjang terhadap keterampilan menggiring bola, karena teknik 
menggiring bola sangat menentukan terhadap seorang pemain dalam suatu pertandingan sepak bola.Lari Zig-Zag adalah merupakan salah satu bentuk latihan yang diperlukan dan di kuasai oleh seorang pemain untuk menunjang dalm teknik, baik membawa atau melewati dan mengolah bola. Sehingga di perlukan keterampilan-keterampilan tertentu yang terarah. Jongging run Kelincahan yang dilakukan oleh atlet atau pemain sepakbola saat berlatih maupun bertanding tergantung pula oleh kemampuan mengkoordinasikan sistem gerak tubuh dengan respon terhadap situasi dan kondisi yang dihadapi.

\section{B. METODE PENELITIAN}

Metode yang akan digunakan dalam penelitian ini adalah metode eksperimen. Menurut Suharsimi arikunto (2006:3) mengatakan bahwa metode eksperimen yaitu suatu metode yang mempergunakan suatu gejala yang disebut perlakuan dan perlakuan ini merupakan kegiatan yang disebut latihan..Metode eksperimen dengan pola Treament By Subjects Designs disingkat dengan T-S Sutrisno Hadi (2004:485), mengatakan bahwa,“ beberapa atau jenis atau variasi treatment diberikan secara berturut-turut kepada kelompok subjek yang sama. Dasar penggunan metode eksperimen adalah percobaan yang diawali dengan tes awal, kemudian diberikan perlakuan dan diakhiri dengan tes akhir, kemudian hasilnya diuji peningkatan persentase hasil tes akhir.Teknik pengumpulan data secara langsung adalah dengan cara peneliti secara langsung mengetahui hasil tes awal (pre-tes) dan tes akhir (post-tes). Adapun yang menjadi variabel dalam penelitian ini adalah variabel bebas dan variabel terikat. Penelitian ini mempunyai 2 variabel bebas (perlakuan) latihan Latihan lari Zig-Zag dan Latihan jongging run dan 1 variabel terikat kecepatan menggiring bola. Rancangan dalam penelitian "PretestPosttest Design". Gambar rancangan penelitian sebagai berikut:

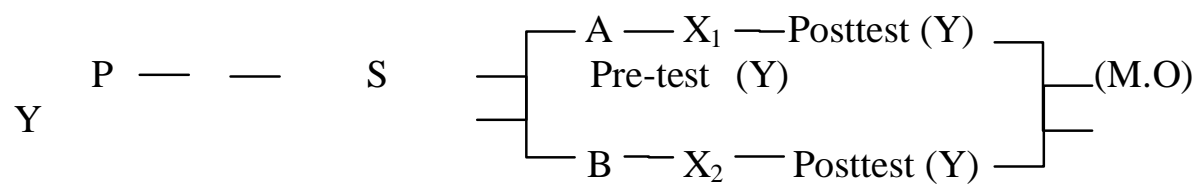

Gambar 1. Rancangan desain penelitian,

Sumber: Sudjana, (1985:18) 


\section{Keterangan:}

$$
\begin{array}{ll}
\mathrm{P} & =\text { Population } \\
\mathrm{S} & =\text { Sampel } \\
\text { Pre-test } & =\text { Tes awal } \\
\mathrm{M} . \mathrm{O} & =\text { Machid ordinat } \\
\mathrm{A} & =\text { Kelompok A (Latihan servis dengan latihan lari Zig-Zag) } \\
\mathrm{B} & =\text { Kelompok B (Latihan servis dengan latihan jongging run) } \\
\mathrm{X}_{1} & =\text { Perlakuan latihan servis dengan latihan lari Zig-Zag } \\
\mathrm{X}_{2} & =\text { Perlakuan latihan servis dengan latihan jongging run } \\
\text { Posttest } & =\text { Tes akhir } \\
\mathrm{Y} & =\text { kecepatan menggiring bola }
\end{array}
$$

\section{HASIL DAN PEMBAHASAN}

Tabel 1. Deskriptif data hasil eksperimen tes awal dan tes akhir Latihan Lari ZigZag Lurus Terhadap Kemampuan Menggiring Bola

\begin{tabular}{lcccccccc}
\hline & & & & & & \multicolumn{3}{c}{$\begin{array}{c}\text { Std. } \\
\end{array}$} \\
& N & Range & Min & Max & Sum & Mean & Deviation & Var \\
\hline $\begin{array}{l}\text { Tes Awal pada } \\
\text { kelompok A }\end{array}$ & 15 & 6.61 & 12.77 & 19.38 & 223.0 & 14.86 & 1.88687 & 3.560 \\
\hline Tes pada kelompok A & 15 & 7.69 & 11.20 & 18.89 & 212.8 & 14.18 & 2.05508 & 4.223
\end{tabular}

Berdasarkan rangkuman hasil analisis tes eksperimen tes awal dan tes akhir pada tabel 1 maka dapat diuraikan sebagai berikut: data tes awal Latihan Lari Zig-Zag Lurus dari 15 sampel diperoleh nilai rata-rata sebesar 14,866 dan standar deviasi 1,887, Data tes akhir Latihan Lari Zig-Zag Lurus dari 20 sampel diperoleh nilai rata-rata sebesar 14,189 dan standar deviasi 2,055.

Tabel 2. Deskriptif data hasil eksperimen tes awal dan tes akhir Latihan Jongging Run Terhadap Kemampuan Menggiring Bola

\begin{tabular}{lrrrrrrrr}
\hline & & & & & \multicolumn{3}{c}{ Std. } \\
& N & Range & Min & Max & Sum & Mean & Deviation & Var \\
\hline Tes Awal pada kelompok B & 15 & 6.61 & 12.77 & 19.38 & 221.0 & 14.73 & 1.92871 & 3.
\end{tabular}




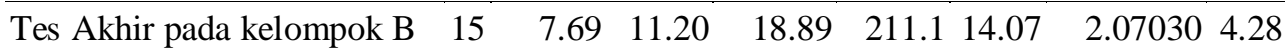

Berdasarkan rangkuman hasil analisis tes eksperimen tes awal dan tes akhir Latihan Jongging Run pada tabel 2 maka dapat diuraikan sebagai berikut: data tes awal Latihan Jongging Run dari 15 sampel diperoleh nilai rata-rata sebesar 14,734 dan standar deviasi 1,928, data tes akhir Latihan Jongging Run dari 15 sampel diperoleh nilai rata-rata sebesar 14,076 dan standar deviasi 2,070. Dengan demikian terdapat perbedaan mean tes awal dan mean tes akhir Latihan Jongging Run sebagai bahan pembanding.

Hasil analisis normalitas data dapat dilihat dalam rangkuman hasil uji normalitas data yang menggunakan uji Kolmogorov Smirnov (KS-Z) pada tabel 3.

Tabel 3. Hasil uji normalitas hasil eksperimen tes awal dan tes akhir 1 Latihan Lari Zig-Zag Lurus Terhadap Kemampuan Menggiring Bola

\begin{tabular}{|ll|r|r|}
\hline & & $\begin{array}{c}\text { Tes Awal Latihan } \\
\text { pada kelompok A }\end{array}$ & $\begin{array}{c}\text { Tes Akhir pada } \\
\text { kelompok A }\end{array}$ \\
\hline N & 15 & 15 \\
Normal Parameters ${ }^{\mathrm{a}, \mathrm{b}}$ & Mean & 14.8667 & 14.1893 \\
& Std. & 1.88687 & 2.05508 \\
Kolmogorov-Smirnov Z & & 0.662 & 0.774 \\
Asymp. Sig. (2-tailed) & & 0.774 & 0.588 \\
\hline
\end{tabular}

Berdasarkan Tabel 3 di atas menunjukkan bahwa hasil penelitian ini menggunakan pengolahan Kolmogorov Smirnov pada taraf signifikan 95\%. Kelompok A yang diberi Latihan Lari Zig-Zag, diperoleh nilai Kolmogorov Smirnov masing-masing 0,662 dan 0,774 dengan tingkat probabilitas 0,774 dan 0,588 lebih besar dari pada nilai $\alpha 0,05$ pada taraf signifikan 95\%. Dengan demikian dapat disimpulkan bahwa data pada kelompok A Latihan Lari Zig-Zag Lurus Terhadap Kemampuan Menggiring Bola berdistribusi normal. 
Tabel 4. Hasil uji normalitas hasil eksperimen tes awal dan tes akhir Latihan Jongging Run Terhadap Kemampuan Menggiring Bola Kaki

\begin{tabular}{|ll|r|r|}
\hline & \multicolumn{1}{|c|}{$\begin{array}{c}\text { Tes Awal pada } \\
\text { kelompok B }\end{array}$} & $\begin{array}{c}\text { Tes Akhir pada } \\
\text { kelompok B }\end{array}$ \\
\hline N & & 15 & 15 \\
Normal Parameters ${ }^{\mathrm{a}, \mathrm{b}}$ & Mean & 14.7340 & 14.0760 \\
& Std. Deviation & 1.92871 & 2.07030 \\
Kolmogorov-Smirnov Z & & 0.840 & 1.019 \\
Asymp. Sig. (2-tailed) & & 0.480 & 0.250 \\
\hline
\end{tabular}

Sedangkan pada Kelompok B yang diberi Latihan Jongging Run, diperoleh nilai Kolmogorov Smirnov masing-masing 0,840 dan 1,019 dengan tingkat probabilitas 0,480 dan 0,250 lebih besar dari pada nilai $\alpha 0,05$ pada taraf signifikan 95\%. Dengan demikian dapat disimpulkan bahwa data pada kelompok B latihan berdistribusi normal.

Tabel 5. paired samples test pada hasil eksperimen tes awal dan tes akhir Latihan Lari Zig-Zag Lurus Terhadap Kemampuan Menggiring

\begin{tabular}{|c|c|c|c|c|c|c|c|c|}
\hline & \multicolumn{5}{|c|}{ Paired Differences } & \multirow[b]{3}{*}{$\mathrm{t}$} & \multirow[b]{3}{*}{$\mathrm{df}$} & \multirow{3}{*}{$\begin{array}{l}\text { Sig. (2- } \\
\text { tailed) }\end{array}$} \\
\hline & \multirow[b]{2}{*}{ Mean } & \multirow[b]{2}{*}{ SD } & \multirow{2}{*}{$\begin{array}{c}\text { SE } \\
\text { Mean }\end{array}$} & \multicolumn{2}{|c|}{$\begin{array}{l}95 \% \text { CI of the } \\
\text { Difference }\end{array}$} & & & \\
\hline & & & & Lower & Upper & & & \\
\hline $\begin{array}{c}\text { Pair } 1 \text { Tes Awal - Tes } \\
\text { Akhir pada } \\
\text { kelompok A }\end{array}$ & .6773 & .320 & .08286 & .49961 & .85506 & 8.17 & 14 & 0.000 \\
\hline
\end{tabular}

Berdasarkan Tabel 5 diperoleh $\mathrm{t}$ hasil output adalah 8,174 dengan probabilitas 0.000. untuk uji two tailed angka probabilitas adalah $0.000 / 2=0.000$. oleh karena $0.000<0.05 / 2=0.025$ maka Ho ditolak sehingga H1 diterima. Dapat disimpulkan siswa SMA Negeri 3 samarinda dalam kemampuan menggiring bola Tabel 6. paired samples test pada hasil eksperimen tes awal dan tes akhir Latihan Jongging Run Terhadap Kemampuan Menggiring Bola Kaki

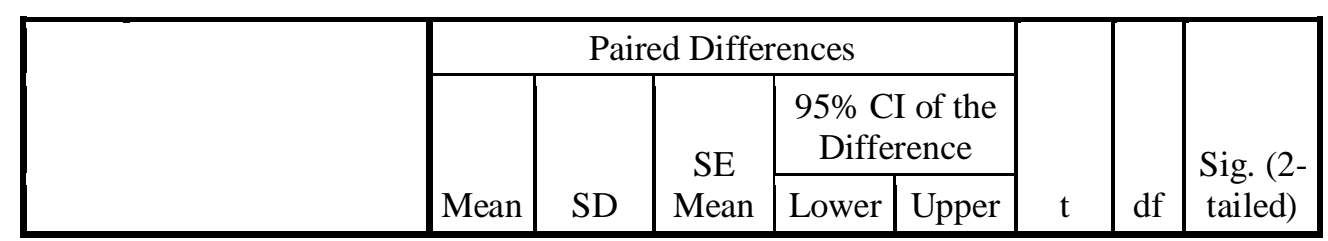




\begin{tabular}{|c|c|c|c|c|c|c|c|c|}
\hline & \multicolumn{5}{|c|}{ Paired Differences } & \multirow[b]{3}{*}{$\mathrm{t}$} & \multirow[b]{3}{*}{ df } & \multirow{3}{*}{$\begin{array}{l}\text { Sig. (2- } \\
\text { tailed) }\end{array}$} \\
\hline & \multirow[b]{2}{*}{ Mean } & \multirow[b]{2}{*}{ SD } & \multirow{2}{*}{$\begin{array}{c}\text { SE } \\
\text { Mean }\end{array}$} & \multicolumn{2}{|c|}{$\begin{array}{l}95 \% \mathrm{CI} \text { of the } \\
\text { Difference }\end{array}$} & & & \\
\hline & & & & Lower & Upper & & & \\
\hline $\begin{array}{l}\text { Pair } 1 \text { Tes Awal - Akhir } \\
\text { pada kelompok B }\end{array}$ & .6580 & .33336 & .08607 & .47339 & .84261 & 7.64 & 14 & .000 \\
\hline
\end{tabular}

Tabel 7. Uji t pada hasil eksperimen tes akhir latihan lari Zig-zag dan tes akhir Latihan Jongging Run Terhadap Kemampuan Menggiring Bola Kaki.

\begin{tabular}{|c|c|c|c|c|c|c|c|c|c|}
\hline & \multicolumn{5}{|c|}{ Paired Differences } & \multirow[b]{3}{*}{$\mathrm{t}$} & & \multirow{3}{*}{$\begin{array}{l}\text { Sig. }(2- \\
\text { tailed) }\end{array}$} \\
\hline & & \multirow[b]{2}{*}{ Mean } & \multirow{2}{*}{$\begin{array}{c}\text { Std.De } \\
\text { v }\end{array}$} & \multirow{2}{*}{$\begin{array}{l}\text { SE } \\
\text { Mean }\end{array}$} & \multicolumn{2}{|c|}{$\begin{array}{l}95 \% \text { C I of the } \\
\text { Difference }\end{array}$} & & & \\
\hline & & & & & Lower & Upper & & df & \\
\hline Pair 1 & $\begin{array}{l}\text { Tes Akhir } \\
\text { pada kelompok A - } \\
\text { Tes Akhir } \\
\text { pada kelo B }\end{array}$ & .1133 & 2.608 & .6736 & -1.3314 & 1.558 & 1.16 & 1 & .000 \\
\hline
\end{tabular}

Berdasarkan Uji Analisis 1 Ada pengaruh Latihan Lari Zig-Zag Terhadap Kemampuan Menggiring Bola Pada Siswa SMA Negeri 3 samarinda. Sesuai hasil uji-t data tes awal dan data tes akhir kemampuan menggiring bola pada kelompok A untuk latihan Lari Zig-Zag Lurus, hasil perhitungan diperoleh nilai t observasi lebih besar dari nilai t tabel pada taraf signifikan 95\%. Hal tersebut membuktikan bahwa hipotesis pertama yang diajukan diterima pada taraf signifikan $95 \%$. Dengan demikian ada peningkatan latihan sebelum diberi latihan Lari Zig-Zag Lurus berpasangan dan sesudah diberikan latihan Lari Zig-Zag Lurus. Jadi $\mathrm{H}_{0}$ ditolak dan $\mathrm{H}_{1}$ di terima. Hasil yang diperoleh tersebut di atas apabila dikaitkan dengan kerangka berpikir maupun teori-teori yang mendasarinya, pada dasarnya hasil penelitian ini mendukung teori yang ada. Hal ini Gerakan tehnik sentuhan bola adalah gerakan penting untuk melakukan dribbling yang baik, paha dan tungkai kaki serta kaki bergerak dengan baik. Menggiring bola tidak hanya membawa bola menyusuri tanah dan lurus kedepan melainkan menghadapi lawan yang jaraknya cukup dekat dan rapat. Hal ini menuntut seorang pemain untuk 
memiliki kemampuan menggiring bola dengan baik. Menggiring bola adalah membawa bola dengan kaki dengan tujuan melewati lawan. Sukatamsi (1988: 161) mengatakan bahwa cara menggiring bola yaitu : posisi kaki menggiring bola sama dengan posisi kaki dalam menendang bola, kaki yang digunakan untuk menggiring bola tidak diayunkan seperti menendang bola, akan tetapi tiap langkah secara teratur menyentuh atau mendorong bola bergulir kedepan dan bola harus selalu dekat dengan kaki, dengan demikian bola mudah dikuasai dan tidak mudah direbut oleh lawan, pada saat menggiring bola lutu kedua kaki harus sedikit ditekuk dan pada waktu kaki menyentuh bola, mata melihat bola, selanjutnya melihat situasi lapangan.

Berdasarkan Uji Analisis 2 Ada pengaruh Latihan Jongging Run Terhadap Kemampuan Menggiring Bola Kaki Pada Siswa SMA Negeri 3 samarinda. Dalam posisi menggiring bola gerakan tehnik sentuhan bola adalah gerakan penting untuk melakukan dribbling yang baik, paha dan tungkai kaki serta kaki bergerak dengan baik. Menggiring bola tidak hanya membawa bola menyusuri tanah dan lurus kedepan melainkan menghadapi lawan yang jaraknya cukup dekat dan rapat. Hal ini menuntut seorang pemain untuk memiliki kemampuan menggiring bola dengan baik. Menggiring bola adalah membawa bola dengan kaki dengan tujuan melewati lawan. Sukatamsi (1988: 161) mengatakan bahwa cara menggiring bola yaitu : posisi kaki menggiring bola sama dengan posisi kaki dalam menendang bola, kaki yang digunakan untuk menggiring bola tidak diayunkan seperti menendang bola, akan tetapi tiap langkah secara teratur menyentuh atau mendorong bola bergulir kedepan dan bola harus selalu dekat dengan kaki, dengan demikian bola mudah dikuasai dan tidak mudah direbut oleh lawan, pada saat menggiring bola lutu kedua kaki harus sedikit ditekuk dan pada waktu kaki menyentuh bola, mata melihat bola, selanjutnya melihat situasi lapangan. Menggiring bola dengan menggunakan kura-kura kaki memberi kesempatan pada pemain untuk berubah-rubah arah serta dapat menghindari lawan yang berusaha merampas bola. Merubah arah dan membelok kekiri maupun kekanan berarti menghindarkan bola dari lawan. Karna dengan demikian tubuh 
pemain yang sedang menggiring bola dapat menutup atau membatasi lawan dengan bola.

Berdasarkan Uji Analisis 3 Ada perbedaan pengaruh antara Latihan Lari Zig-Zag Lurus dan Latihan Jongging Run Terhadap Kemampuan Menggiring Bola Kaki Pada Siswa SMA Negeri 3 samarinda kedua bentuk latihan ini memberikan pengaruh atau peningkatan yang positif terhadap kemampuan menggiring bola, namun bila dibandingkan dengan melihat hasil yang diperoleh pada rata-rata tes akhir serta pengujian statistik uji-t tidak berpasangan, maka Latihan Lari Zig-Zag Lurus lebih produktif dan efisien. Sebab didalam melakukan latihan ini memiliki tingkat kecepatan yang lebih tinggi. kelincahan dan kecepatan dibutuhkan oleh seseorang pemain sepak bola dalam menghadapi situasi tertentu dan kondisi pertandingan yang menuntut unsur kecepatan dan kelincahan dalam bergerak untuk menguasai bola maupun dalam bertahan untuk menghindari benturan yang mungkin terjadi. Kecepatan dan kelincahan dapat dilatih secara bersama-sama, baik dengan bola maupun tanpa bola. Bagi seorang pemain sepakbola situasi yang berbeda-beda selalu dihadapi dalam setiap pertandingan, juga seorang pemain sepak bola menghendaki gerakan yang indah dan cepat sering dilakukan unsur kecepatan dan kelincahan. Teknik dalam permainan sepak bola meliputi 2 macam teknik yaitu : teknik dengan bola dan tanpa bola. Teknik dasar bermain sepakbola yang harus dikuasai meliputi menendang bola, menghentikan bola, mengontrol bola, gerak tipu, tackling, lemparan kedalam dan teknik menjaga gawang. Mengontrol bola diantaranya adalah menjaga dan melindungi bola dengan kaki untuk terus dibawa kedepan disebut juga menggiring (dribbling).

\section{KESIMPULAN}

Kesimpulan hasil penelitian menunjukkan bahwa: 1). Ada pengaruh antara latihan Lari Zig-Zag Terhadap Kemampuan Menggiring Bola Pada Siswa SMA Negeri 3 samarinda, diperoleh nilai $\mathrm{t}_{\mathrm{o}}=8.174 \geq \mathrm{t}_{0,05}=2,145$ dengan nilai probabilitas signifikansi yang diperoleh $0,000<\alpha 0,05 ; 2)$. Ada pengaruh antara 
latihan Jongging Run Terhadap Kemampuan Menggiring Bola Pada Siswa SMA Negeri 3 samarinda, diperoleh nilai $\mathrm{t}_{\mathrm{o}}=7.645 \geq \mathrm{t}_{0,05}=2,145$, dengan nilai probabilitas signifikansi yang diperoleh $0,000<\alpha 0,05 ; 3)$. Ada perbedaan pengaruh latihan Pengaruh Latihan lari Zig-Zag Dan Latihan Jongging Run Terhadap Kemampuan Menggiring Bola Pada SMA Negeri 3 samarinda yang diperoleh $0,000<\alpha 0,05=0.281$

\section{DAFTAR PUSTAKA}

Agusta Husni, Lukman Hakim, M.AR.Gayo, 1992, Buku Pintar Olahraga, Jakarta: CV. Mawar Gempit

Bompa, Tudor O. 1983. Theory and Methodology of Training. Dubuge : Kendall/ Hunt Publishing Company

Budiharsono, Teguh, 2007, Pengantar Penulisan Karya Ilmiah. Samarinda: Cartel Books.

Dangsina Moeloek dan Arjadino Tjokro. 1984. Kesehatan dan Olahraga. Jakarta : Fakultas Kedokteran Universitas Indonesia

Engkos Kosasih. 1985. Olahraga Teknik dan Program Latihan. Jakarta: Akademika Presindo.

Hadi, Sutrisno, 1989, Statistik jilid II, Bandung: Andi Offset

Harsono, 1988, Coaching dan Aspek-aspek Psikologis Dalam Coaching, Jakarta: CV. Tambak Kusuma.

Harsono, dkk, 2002, Buku II Perkembangan Dan Belajar Gerak, Jakarta: Depdiknas.

Hasan, Iqbal, 2002, Pokok-Pokok Metodologi Penelitian dan Aplikasinya, Jakarta: Ghalia Indonesia.

Jonath.U.E. Haag dan R. Krembel. 1984. Atletik II. Jakarta : PT. Rosda Jayaputra

Luxbacher,C.A .1998. sepak bola Jakarta: PT. Grafinda. Malang (UM Pres).

Marsuki, Saleh, 2000, Pedoman Penulisan Karya Ilmiah, Skripsi, Laporan Penelitian,Tesis,Disertasi,Artikel,Makalah, Malang: Universitas Negeri Malang 
Muhajir, 2007, Pendidikan Jasmani dan Kesehatan, Jakarta: Erlangga.

Nurhasan, 1986, Tes dan Pengukuran, Jakarta: Depdikbud Universitas Terbuka

Sajoto, 1995, Peningkatan dan Pembinaan kekuatan Kondosi Fisik Dalam Olahraga, Semarang: Dahara Prize. 